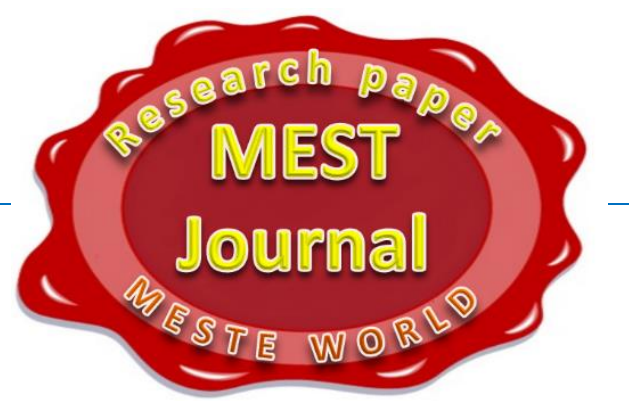

\title{
RUBISCO PROTEIN PRODUCTION - LCA APPROACH
}

\section{Dubravka Skunca}

Faculty of Business and Law, Union - Nikola Tesla University, Belgrade, Serbia

\section{Hedi Romdhana}

AgroParisTech, Paris, France

\section{Rob Brouwers}

Royal Cosun, North Brabant, Netherlands

\section{CMESTE}

JEL Category: D15, 013

\begin{abstract}
The objective of this paper was to assess the environmental performance of the system of RuBisCo protein extraction and isolation from sugar beet leaves. Life cycle assessment (LCA) calculations have been completed to identify and quantify the environmental impacts from a cradle-to-cradle perspective covering seven subsystems: milling and extraction, heat treatment, centrifugation, microfiltration, ultrafiltration, chromatography and spray drying. In this paper, six environmental impact categories were analyzed: global warming potential, ozone layer depletion, energy demand, eutrophication potential, acidification potential, and land use. When RuBisCo protein extraction and isolation from different raw materials are compared, the only crop that has a lower environmental impact than sugar beet leaves is alfalfa, while the higher environmental impact has yellow mustard, ryegrass (mixture), Italian ryegrass, Brussels sprouts, English ryegrass, carrot leaves, leaf radish, and chicory. The comparison of environmental impact categories of different protein concentrates indicated that protein powder containing RuBisCo affected the environment less than egg protein concentrate. Direct comparison to other highly functional plant proteins was not possible as these are not in the market or have no LCA data available. RuBisCo was more environmentally impacting than regular soy protein. Our results for RuBisCo were in accordance with the low end of the range of results for microalgae, which is representing Chlorella HTF (heterotrophic fermenter), for most of the analyzed impact categories. This study found that the largest contributor to the environmental profile of the entire system of RuBisCo protein extraction and isolation from sugar beet leaves is the usage of electricity, while mitigation options for optimization of environmental impacts rely on the energy pinch approach for spray drying 1 .
\end{abstract}

The address of the corresponding author:

Dubravka Skunca

莑=7dubravka.skunca@ppf.edu.rs
Keywords: life cycle assessment, RuBisCo, environmental impact, GreenProtein

\footnotetext{
1 The text of the paper reflects only the author's view and the Bio Based Industries Joint Undertaking is not responsible for any use that may be made of the information it contains.
} 


\section{INTRODUCTION}

This paper covers LCA analysis of the RuBisCo protein extraction and isolation from sugar beet leaves related to the GreenProtein project, which has received funding from the Bio-Based Industries Joint Undertaking under the European Union's Horizon 2020 research and innovation program. The GreenProtein project has established a demo plant for the extraction and isolation of RuBisCo protein from sugar beet leaves at an industrial scale in Dinteloord, the Netherlands. It allows defining of the optimal conditions for the extraction process to be an easily replicable system in the whole EU (GP, 2020).

\section{MATERIALS AND METHODS}

LCA methodology used in the research is based on the standard published by the International Organization for Standardization (ISO) and includes the following steps: mapping the process (setting the goal), setting scope and boundaries, collecting data, calculating and analyzing the results (ISO, 2006).

Environmental impact categories were calculated using the IMPACT 2002+ method. Ecoinvent and Agri-footprint database, as well as SimaPro 9.0 software, was used to process the inventories.

\section{MAPPING THE PROCESS}

The goal of the study is to provide insight into the environmental impacts of RuBisCo protein extraction and isolation from sugar beet leaves by using the LCA approach. The functional unit (FU) has been established as $1 \mathrm{~kg}$ of protein powder containing RuBisCo (87.72 kg of sugar beet leaves is transformed into a functional unit). Activities taken into consideration were the transport of the leaves from the field to the demo plant and all activities connected to milling and extraction, heat treatment, centrifugation, microfiltration, ultrafiltration, chromatography, and spray drying.

\section{SETTING SCOPE AND BOUNDARIES}

This study aims to evaluate the environmental impacts throughout the life cycle of RuBisCo protein extraction and isolation from sugar beet leaves through a cradle-to-cradle perspective and to propose improvement actions for the environmental impact reduction.

The system boundaries covered seven subsystems: milling and extraction, heat treatment, centrifugation, microfiltration, ultrafiltration, chromatography, and spray drying.

\section{COLLECTING DATA, CALCULATING AND ANALYZING THE RESULTS AND INVENTORY ANALYSIS}

AgroParisTech has provided data needed for LCA calculations. These data were the components of the life cycle inventory for all subsystems. Transport, consumption of water, chemicals, energy, waste, and wastewater were calculated per $1 \mathrm{~kg}$ of protein powder containing RuBisCo, as it represents the chosen functional unit.

\section{LIFE CYCLE ASSESSMENT RESULTS}

Environmental impact categories analyzed in this research were Global Warming Potential (GWP), Ozone Layer Depletion (OLD), Energy Demand (ED), Eutrophication Potential (EP), Acidification Potential (AP), and Land Use (LU). For the entire system of RuBisCo protein extraction and isolation from sugar beet leaves GWP results were $16.41 \mathrm{~kg} \mathrm{CO}$-eq., OLD results were 1.21 mg CFC-11-eq., ED results were 205.24 MJ, EP results were $4.73 \mathrm{~g} \mathrm{PO}_{4} \mathrm{P}$-lim, AP results were $620.76 \mathrm{~g} \mathrm{SO}_{2}$-eq., while LU results were $0.19 \mathrm{~m}^{2}$ org. arable.

Amount of waste dominated contributions of processes carried out during milling and extraction in the case of GWP, OLD, ED, and AP. Usage of calcium chloride had the highest impact for EP, while transport had a predominant impact for LU. For this subsystem GWP results were 3.50 $\mathrm{kg} \mathrm{CO}$-eq., OLD results were $0.40 \mathrm{mg}$ CFC-11eq., ED results were $46.68 \mathrm{MJ}$, EP results were $0.99 \mathrm{~g} \mathrm{PO}_{4} \mathrm{P}$-lim, AP results were $324.79 \mathrm{~g} \mathrm{SO}_{2}-$ eq., while LU results were $0.11 \mathrm{~m}^{2}$ org. arable. For OLD, EP, AP, and LU milling and extraction dominated with the impact on the environment in comparison with all other subsystems (Figure 1$6)$. 


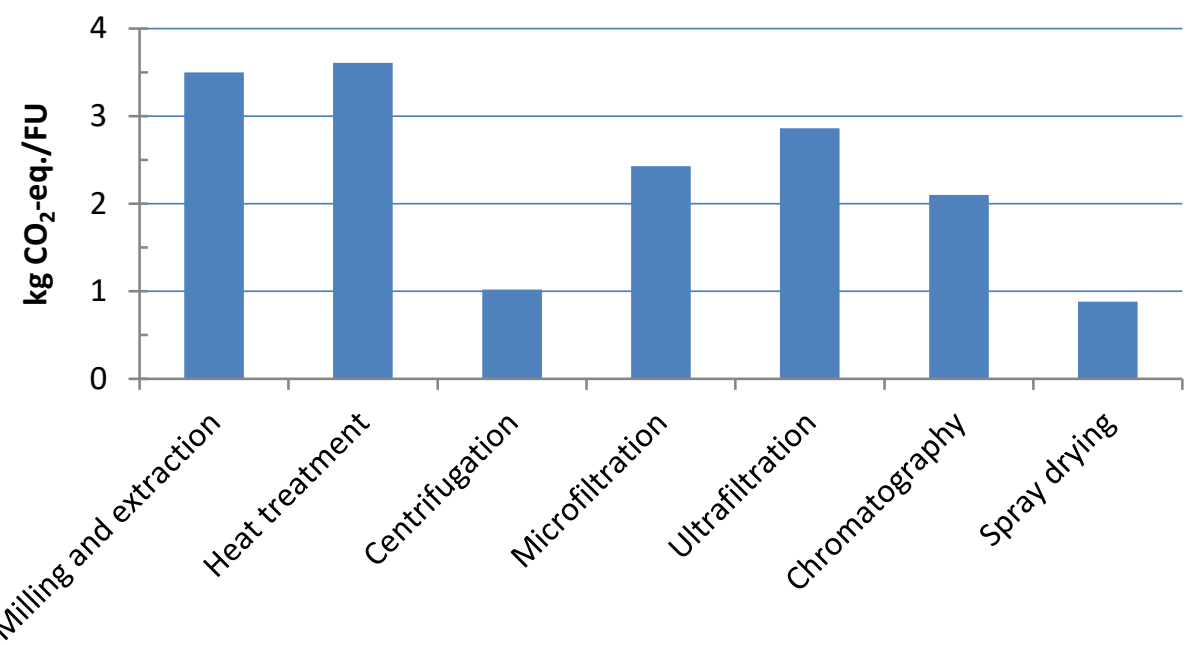

Figure 1. Global Warming Potential (GWP) per functional unit (FU) for each of the subsystems.

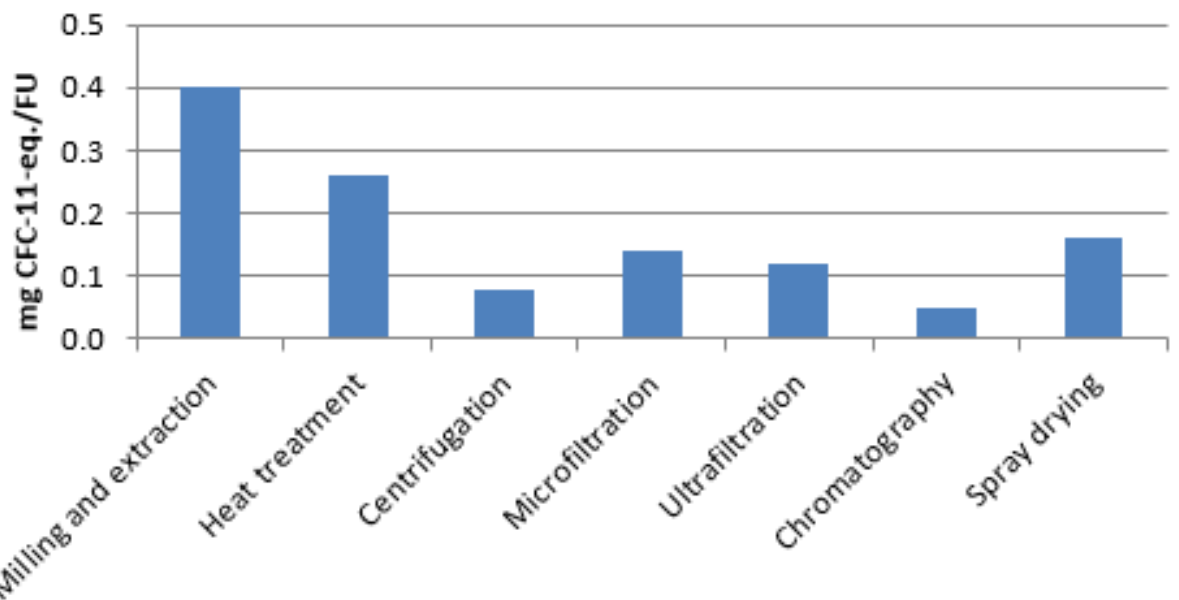

Figure 2. Ozone Layer Depletion (OLD) per functional unit (FU) for each of the subsystems

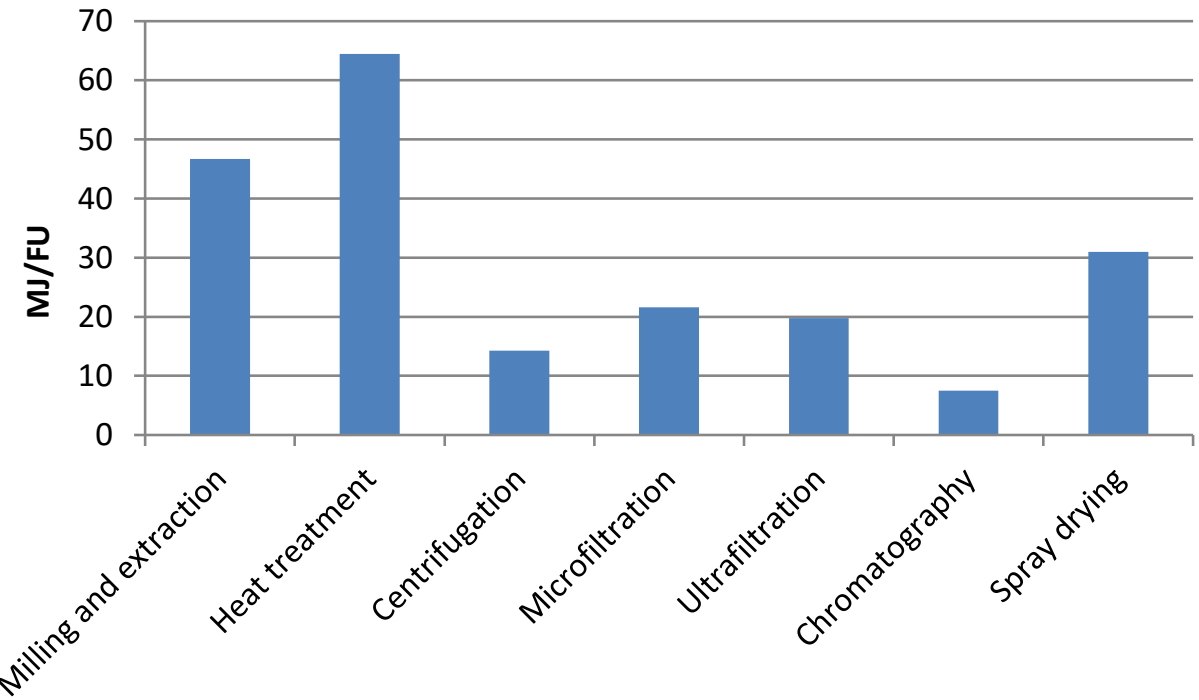

Figure 3. Energy Demand (ED) per functional unit (FU) for each of the subsystems. 


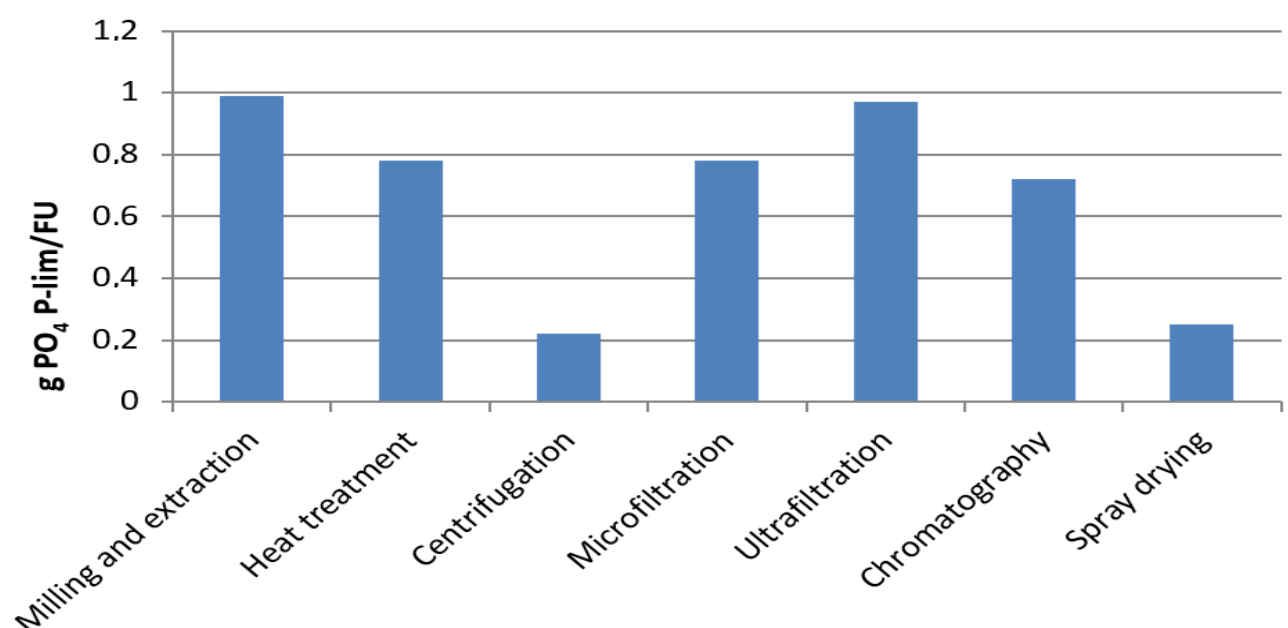

Figure 4. Eutrophication Potential (EP) per functional unit (FU) for each of the subsystems

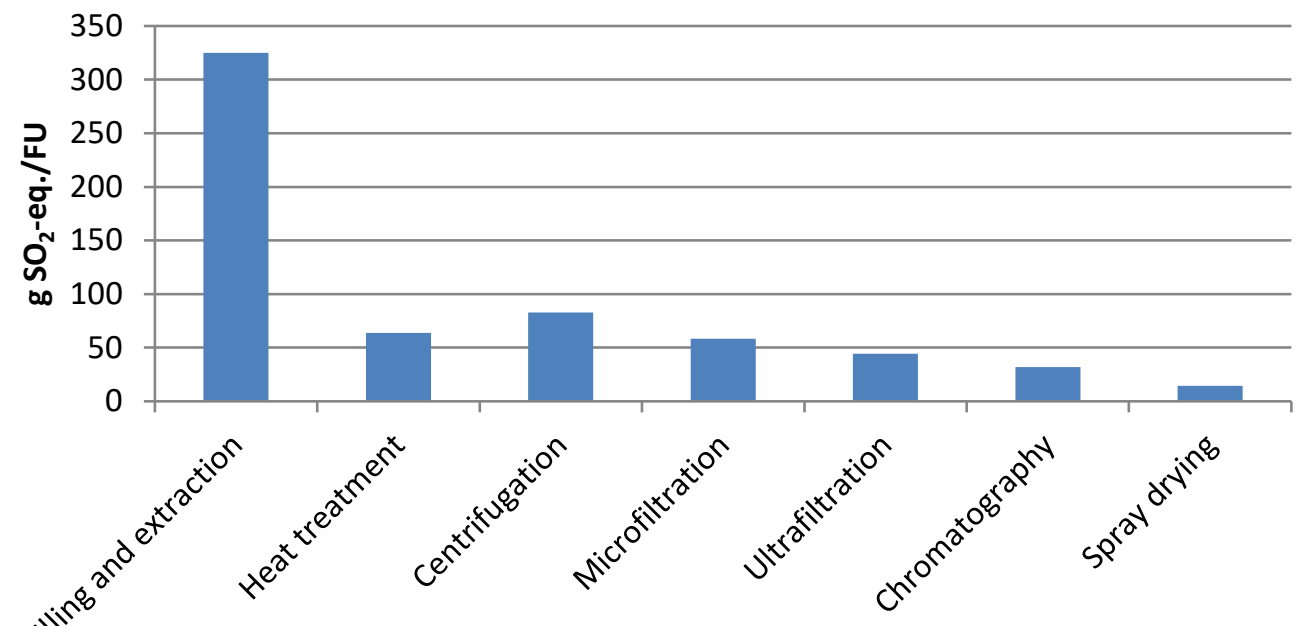

Figure 5. Acidification Potential (AP) per functional unit (FU) for each of the subsystems

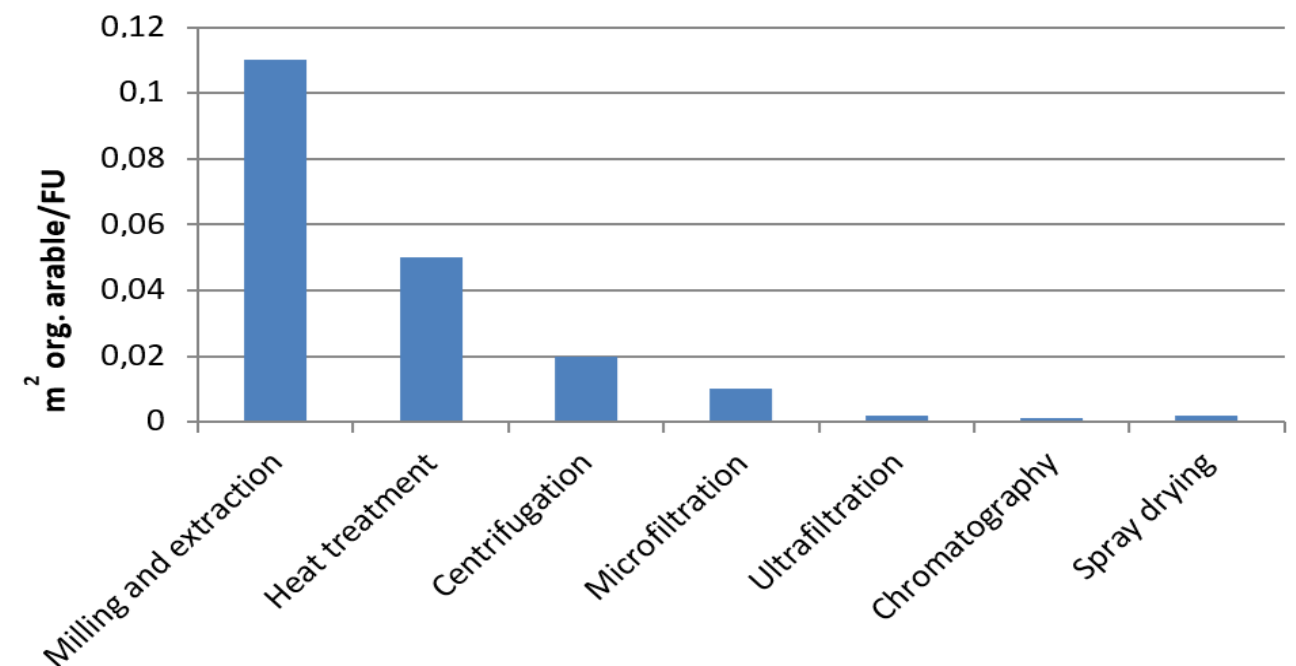

Figure 6. Land Use (LU) per functional unit (FU) for each of the subsystems 
Electricity usage dominated environmental contributions of processes carried out during heat treatment in terms of all examined impact categories - GWP, OLD, ED, EP, AP, and LU. For this subsystem GWP results were $3.61 \mathrm{~kg} \mathrm{CO}$ eq., OLD results were $0.26 \mathrm{mg}$ CFC-11-eq., ED results were $64.48 \mathrm{MJ}$, EP results were $0.78 \mathrm{~g}$ $\mathrm{PO}_{4} \mathrm{P}$-lim, AP results were $63.97 \mathrm{~g} \mathrm{SO}_{2}$-eq., while LU results were $0.05 \mathrm{~m}^{2}$ org. arable. For GWP and ED heat treatment dominated with the impact on the environment in comparison with all other subsystems (Figure 1-6).

The contributions of processes carried out during centrifugation were dominated by usage of electricity in the case of GWP, ED, and EP and by the amount of waste for OLD, AP, and LU. For this subsystem GWP results were $1.02 \mathrm{~kg} \mathrm{CO}$ eq., OLD results were $0.08 \mathrm{mg}$ CFC-11-eq., ED results were $14.25 \mathrm{MJ}$, EP results were $0.22 \mathrm{~g}$ $\mathrm{PO}_{4} \mathrm{P}$-lim, AP results were $82.86 \mathrm{~g} \mathrm{SO}_{2}$-eq., while LU results were $0.02 \mathrm{~m}^{2}$ org. arable (Figure 1-6).

Amount of wastewater dominated contributions of processes carried out during microfiltration in the case of GWP, EP, and AP. Usage of natural gas had the highest impact for ED and amount of waste for LU. For this subsystem GWP results were $2.43 \mathrm{~kg} \mathrm{CO}$-eq., OLD results were $0.14 \mathrm{mg}$ CFC-11-eq., ED results were $21.58 \mathrm{MJ}$, EP results were $0.78 \mathrm{~g} \mathrm{PO}_{4} \mathrm{P}$-lim, AP results were $58.18 \mathrm{~g} \mathrm{SO}_{2}$-eq., while LU results were $0.01 \mathrm{~m}^{2}$ org. arable (Figure 1-6).

The contributions of processes carried out during ultrafiltration were dominated by the amount of wastewater in the case of GWP, EP, and AP, by the usage of natural gas for OLD and ED, and by the usage of demineralized water for LU. For this subsystem GWP results were $2.86 \mathrm{~kg} \mathrm{CO}$-eq., OLD results were $0.12 \mathrm{mg}$ CFC-11-eq., ED results were $19.74 \mathrm{MJ}$, EP results were $0.97 \mathrm{~g}$ $\mathrm{PO}_{4} \mathrm{P}$-lim, AP results were $44.29 \mathrm{~g} \mathrm{SO}_{2}$-eq., while LU results were $0.002 \mathrm{~m}^{2}$ org. arable (Figure 1-6).

Amount of wastewater dominated contributions of processes carried out during chromatography in the case of GWP, ED, EP, and AP, while usage of demineralized water had the highest impact for OLD and LU. For this subsystem GWP results were $2.10 \mathrm{~kg} \mathrm{CO}$-eq., OLD results were $0.05 \mathrm{mg}$ CFC-11-eq., ED results were $7.52 \mathrm{MJ}$, EP results were $0.72 \mathrm{~g} \mathrm{PO}_{4} \mathrm{P}$-lim, AP results were $32.10 \mathrm{~g}$
$\mathrm{SO}_{2}$-eq., while LU results were $0.001 \mathrm{~m}^{2}$ org. arable (Figure 1-6).

The contributions of processes carried out during spray drying were dominated by the amount of wastewater in the case of GWP, EP, and AP, by the usage of natural gas for OLD and ED, and the usage of electricity for LU. For this subsystem GWP results were $0.88 \mathrm{~kg} \mathrm{CO}$-eq., OLD results were $0.16 \mathrm{mg}$ CFC-11-eq., ED results were 31.00 MJ, EP results were $0.25 \mathrm{~g} \mathrm{PO}_{4} \mathrm{P}$-lim, AP results were $14.57 \mathrm{~g} \mathrm{SO}_{2}$-eq., while LU results were $0.002 \mathrm{~m}^{2}$ org. arable (Figures 1-6).

\section{DISCUSSION OF RESULTS}

Contributions of processes involved in the RuBisCo protein extraction and isolation to GWP, OLD, ED, EP, AP, and LU have been examined since activities, inputs, and outputs are influenced by them. The first process Chemicals included calcium chloride, sodium metabisulfite, and sodium hydroxide used in subsystems 1-7. All types of energy and water used across the entire process were grouped under second process Resources. The third process Transport included transport of sugar beet leaves considered as part of subsystem 1 . The fourth process named Waste and wastewater covered waste and wastewater from all subsystems.

The main environmental hotspot for environmental impact categories is the usage of electricity. Resources have been identified as the largest contributor to GWP in the second $(99.38 \%)$, and third $(60.50 \%)$ subsystem, as well as to OLD in heat treatment $(99.85 \%)$ and subsystems 4-7. Resources had predominant contributions for ED in subsystems 2-5, as well as for spray drying (93.31\%). Resources were the prevailing factor for EP in subsystems 2-3 and AP in heat treatment $(99.48 \%)$. Concerning LU Resources had predominant contributions in heat treatment (99.99\%) and subsystems 4-7.

Waste and wastewater had predominant contributions to GWP in milling and extraction $(36.59 \%)$ and in subsystems $4-7$, as well as to OLD in the first $(37.05 \%)$ and third subsystem (55.39\%). Waste and wastewater have been identified as the largest contributor to ED in the first $(32.63 \%)$ and sixth subsystem (81.97\%). Also, Waste and wastewater had the largest 
contributions for EP in subsystems 4-7, for AP in milling and extraction (73.20\%), and in subsystems 3-7 and for LU in centrifugation (55.66\%).

Chemicals had predominant contributions to EP in milling and extraction (46.37\%), while Transport was the largest contributor to LU in the first subsystem (35.40\%).

\section{SENSITIVITY ANALYSIS}

Two types of sensitivity analysis were performed: the first concentrated on method change, while the second focused on potentially more optimized options for RuBisCo protein extraction and isolation from sugar beet leaves.

Sensitivity analysis was conducted by changing the assessment method from IMPACT 2002+ to CML IA baseline (Skunca et al., 2018). Method change had influenced the GWP results, while OLD results remained the same. GWP results for RuBisCo protein extraction and isolation from sugar beet leaves were $7.81 \%$ higher.

The sensitivity analysis for RuBisCo protein extraction and isolation from sugar beet leaves reviewed potentially more optimized options (Smetana et al., 2017).

The energy pinch approach for the spray drying consists of recovering part of the outlet gas to preheat the drying air. Based on the pinch analysis, a saving of $17.52 \%$ on primary energy can be obtained if a pinch of $20^{\circ} \mathrm{C}$ is considered between the discharged drying air and the drying air supplied into the dryer. The sensitivity analysis displays the lowering of the environmental impact of spray drying for $2.16 \%$ for GWP and $12.26 \%$ for ED.

The spray drying could be replaced with freezedrying, which involves three steps: (a) freezing of protein gel between $-30^{\circ} \mathrm{C}$ and $-50^{\circ} \mathrm{C}$; (b) primary drying under vacuum, the moisture content is removed by sublimation at a temperature above $20^{\circ} \mathrm{C}$ and (c) final drying under vacuum at a positive temperature below $50^{\circ} \mathrm{C}$. This technique transforms the protein gel into protein powder and preserves the biological properties of the RuBisCo. In this case, sensitivity analysis showed seven times higher environmental impact for GWP and 2.93 times higher result for ED in comparison with spray drying, as the result of using 51.72 times more electric energy.

The thermal conditioning consists of storing the final product in the liquid state. To ensure safe storage while avoiding microbiological development, pathogens must be reduced by a pasteurization step at $70-80^{\circ} \mathrm{C}$. Subsequently, the protein gel is cooled at ambient temperature. If thermal conditioning is used instead of spray drying, the result of sensitivity analysis shows a higher environmental impact for GWP for $66.26 \%$ in comparison with spray drying, because of using 7.17 times more electricity for thermal conditioning than for spray drying. But the ED result was $16.48 \%$ lower in comparison with spray drying since thermal conditioning requires 3.25 times less natural gas than spray drying.

The outcomes of the sensitivity analysis show how the environmental results are affected by the method change, while the choice of the approach for the seventh subsystem of the RuBisCo protein extraction and isolation from sugar beet leaves plays a relevant role in the environmental profile. Freeze drying has a high environmental impact in categories GWP and ED in comparison with the energy pinch approach and thermal conditioning. Thermal conditioning has a slightly lower environmental impact related to ED than the energy pinch approach, but the energy pinch approach still has significantly lower results for GWP than thermal conditioning. If the energy pinch approach for spray drying would be used, the environmental impact of the seventh subsystem would be reduced by $2.16 \%$ for GWP and $12.26 \%$ for ED. Out of examined potentially more optimized options, the energy pinch approach for spray drying has been proven to be the best solution.

\section{IMPROVEMENT ACTIONS}

Process design improvement of the RuBisCo protein extraction and isolation from sugar beet leaves could be focused on mitigation options for environmental impacts optimization which rely on implementing an energy pinch approach for spray drying, as it has a lower environmental impact in comparison with freeze-drying and thermal conditioning. 
10 COMPARISON OF RUBISCO PROTEIN EXTRACTION AND ISOLATION FROM DIFFERENT CROPS

When RuBisCo protein extraction and isolation from different raw materials are compared, the only crop that has a lower environmental impact in all examined impact categories than sugar beet leaves is alfalfa, while the higher environmental impact has yellow mustard, ryegrass (mixture), Italian ryegrass, Brussels sprouts, English ryegrass, carrot leaves, leaf radish, and chicory, which has the highest environmental impact (Table 1). LCA analysis for these crops has included the same 7 subsystems (excluding transport) of RuBisCo protein extraction and isolation, as in the case of sugar beet leaves.

Table 1. Environmental impact comparison of different RuBisCo protein sources per $1 \mathrm{~kg}$ of protein powder containing RuBisCo

\begin{tabular}{|c|c|c|c|c|c|c|}
\hline \multirow[b]{2}{*}{ Protein source } & \multicolumn{6}{|c|}{ Environmental impact ${ }^{2}$} \\
\hline & $\begin{array}{c}\mathrm{GWP} \\
\left(\mathrm{kg} \mathrm{CO}_{2 \text { eq }}\right)\end{array}$ & $\begin{array}{c}\text { OLD } \\
\left(\mathrm{mg} \mathrm{CFC}-11_{\text {eq }}\right)\end{array}$ & ED (MJ) & $\begin{array}{c}\mathrm{EP} \\
\left(\mathrm{g} \mathrm{PO} \mathrm{P}_{4} \mathrm{P} \text {-lim) }\right.\end{array}$ & $\begin{array}{c}\mathrm{AP} \\
\left(\mathrm{g} \mathrm{SO}_{2} \text { eq }\right)\end{array}$ & $\begin{array}{l}\mathrm{LU} \\
\left(\mathrm{m}^{2}\right)\end{array}$ \\
\hline Sugar beet leaves 3 & 15.64 & 1.12 & 194.54 & 4.57 & 586.12 & 0.15 \\
\hline Alfalfa & 8.49 & 0.61 & 105.71 & 2.48 & 318.57 & 0.08 \\
\hline Yellow mustard & 21.89 & 1.57 & 272.30 & 6.40 & 820.20 & 0.20 \\
\hline Ryegrass (mixture) & 26.27 & 1.88 & 326.60 & 7.69 & 984.09 & 0.25 \\
\hline Italian ryegrass & 29.86 & 2.14 & 371.30 & 8.74 & 1119.55 & 0.28 \\
\hline Brussels sprouts & 33.64 & 2.41 & 419.00 & 9.85 & 1258.37 & 0.31 \\
\hline English ryegrass & 37.19 & 2.66 & 462.40 & 10.87 & 1393.86 & 0.35 \\
\hline Carrot leaves & 78.69 & 5.58 & 980.20 & 23.05 & 2950.20 & 0.74 \\
\hline Leaf radish & 78.69 & 5.58 & 980.20 & 23.05 & 2950.20 & 0.74 \\
\hline Chicory & 131.39 & 9.41 & 1635.10 & 38.41 & 4926.90 & 1.23 \\
\hline
\end{tabular}

Table 2. Environmental impact comparison of different protein sources per $1 \mathrm{~kg}$ of product. ${ }^{4}$

\begin{tabular}{|c|c|c|c|c|c|c|c|}
\hline \multirow[b]{2}{*}{ Protein source } & \multirow{2}{*}{$\begin{array}{l}\text { DM } \\
(\%)\end{array}$} & \multirow{2}{*}{$\begin{array}{l}\text { Protein } \\
(\%)\end{array}$} & \multicolumn{5}{|c|}{ Environmental impact } \\
\hline & & & $\begin{array}{c}\text { GWP } \\
\left(\mathrm{kg} \mathrm{CO}_{2 \text { eq }}\right)\end{array}$ & $\begin{array}{c}\text { OLD } \\
\text { (mg CFC-11 eq) }\end{array}$ & $\begin{array}{l}\text { ED } \\
(\mathrm{MJ})\end{array}$ & $\begin{array}{c}\mathrm{AP} \\
\left(\mathrm{g} \mathrm{SO}_{2 \text { eq }}\right)\end{array}$ & $\begin{array}{l}\text { LU } \\
\left(\mathrm{m}^{2}\right)\end{array}$ \\
\hline $\begin{array}{l}\text { Sugar beet leaves } \\
\text { protein powder }\end{array}$ & 95 & $92.15^{a}$ & 16.41 & 1.21 & 205.24 & 620.76 & 0.19 \\
\hline Soy protein & $92^{1, s p c}$ & $\begin{array}{l}87^{2, \text { spi }} \\
90^{3, \text { spi }}\end{array}$ & $\begin{array}{c}5.14^{1, \mathrm{spc}} \\
6^{2, \mathrm{spi}, \mathrm{kp}} \\
20.2^{3, \mathrm{spi}}\end{array}$ & $0.02^{1, \mathrm{spc}}$ & $\begin{array}{c}2.5^{3, \mathrm{spi}} \\
19.3^{1, \mathrm{spc}}\end{array}$ & $48.83^{1, \mathrm{spc}}$ & $\begin{array}{l}4.6^{1, \mathrm{spc}} \\
6^{2, \mathrm{spi}, \mathrm{kp}}\end{array}$ \\
\hline Whey concentrate & $86-89^{4}$ & $\begin{array}{l}60^{4,5} \\
80^{6, k p}\end{array}$ & $\begin{array}{c}7.48^{5} \\
0.8-7.4^{1} \\
12.1^{7} \\
28-43^{8, \mathrm{kp}} \\
40.6^{6, \mathrm{kp}}\end{array}$ & $\begin{array}{c}0.01-0.06^{4} \\
3.33^{5} \\
3.8^{6, k p}\end{array}$ & \begin{tabular}{|c|}
$58.1^{7}$ \\
$83.3^{5}$ \\
$10.7-39.4^{1}$
\end{tabular} & $\begin{array}{c}0.05-1.5^{1} \\
56.6^{5}\end{array}$ & $\begin{array}{l}0.26- \\
8.27^{1}\end{array}$ \\
\hline Egg protein concentrate 4 & 85 & 80 & 23.4 & 1.01 & 183 & 4000 & 40.1 \\
\hline Microalgae $^{4}$ & 96 & 55 & $14.7-245.1$ & $0.9-19.8$ & $\begin{array}{l}217.1- \\
4181.3\end{array}$ & $\begin{array}{l}260.5- \\
1407.5\end{array}$ & $1.7-5.4$ \\
\hline
\end{tabular}

${ }^{2}$ Fine particulate matter formation is also important indicator, but sufficient data are not available.

${ }^{3}$ Environmental impact results for sugar beet leaves in Table 2 are given without transport, since transport was not included in results of other crops.

${ }^{4}$ Studies of protein sources in Table 3 include different production processes. 
Legend for table 2: DM - dry matter; ${ }^{a}$ The protein content includes $62 \%$ of RuBisCo protein, source AgroParisTech; ${ }^{\mathrm{spc}}$ - soy protein concentrate; spi - soy protein isolate; ${ }^{\mathrm{kp}}$ - per kg protein; ${ }^{1}$ ecoinvent v3 and Agri-footprint database; ${ }^{2}$ Thrane et al., 2016; ${ }^{3}$ Berardy et al., 2015; ${ }^{4}$ Smetana et al., 2017; ${ }^{5}$ Smetana et al., 2016; ${ }^{6}$ Wiedemann et al., 2017; ${ }^{7}$ Kim et al., 2013; ${ }^{8} \mathrm{Nijdam}$ et al., 2012.

\section{COMPARISON OF DIFFERENT PROTEIN SOURCES}

The environmental impact of RuBisCo protein extraction and isolation from sugar beet leaves has been compared to the impact of other protein sources based on values found in the literature (Table 2). The comparison of environmental impact categories of different protein concentrates indicated that protein powder containing RuBisCo affected the environment less than egg protein concentrate but was more environmentally impacting than soy protein. The comparison of environmental impact results of protein powder containing RuBisCo with whey concentrate depended on the chosen study since results for whey concentrate differ in the literature. The wide range of results for microalgae in Table 2 covers different cultivation systems for Chlorella and Spirulina microalgae (Smetana et al., 2017). Our results were in accordance with the low end of the range of results for microalgae, which is representing Chlorella HTF (heterotrophic fermenter), for most of the analyzed impact categories.

\section{CONCLUSIONS}

When RuBisCo protein extraction and isolation from different raw materials are compared, the only crop that has a lower environmental impact than sugar beet leaves is alfalfa, while yellow mustard, ryegrass (mixture), Italian ryegrass, Brussels sprouts, English ryegrass, carrot leaves, leaf radish, and chicory have a higher environmental impact. The comparison of environmental impact categories of different protein concentrates indicated that protein powder containing RuBisCo affected the environment less than egg protein concentrate. Direct comparison to other highly functional plant proteins was not possible as these are not in the market or have no LCA data available. RuBisCo was more environmentally impacting than regular soy protein. Our results for RuBisCo were in accordance with the low end of the range of results for microalgae, which is representing Chlorella HTF (heterotrophic fermenter), for most of the analyzed impact categories. The main hotspot for the environmental profile of the system of RuBisCo protein extraction and isolation from sugar beet leaves is the usage of electricity. Process design improvement is focused on implementing an energy pinch approach for spray drying. Also change to renewable electricity sources will have a positive impact on the environmental profile.

\section{WORKS CITED}

Berardy, A., Costello, C., \& Seager, T. (2015). Life Cycle Assessment of Soy Protein Isolate. Sustainable Systems and Technologies. Michigan: United States.

GP. (2020). GreenProtein project, BBI JU, Horizon 2020, European Commission. Retrieved from GreenProtein project: greenproteinproject.eu

ISO. (2006). ISO 14040:2006 Environmental management - Life cycle assessment - Principles and framework. Geneva: International Organization for Standardization.

Kim, D., Thoma, G., Nutter, D., Milani, F., Ulrich, R., \& Norris, G. (2013). Life cycle assessment of cheese and whey production in the USA. The International Journal of Life Cycle Assessment, 18, 10191035. doi: org/10.1007/s11367-013-0553-9

Nijdam, D., Rood, T., \& Westhoek, H. (2012). The price of protein: Review of land use and carbon footprints from life cycle assessments of animal food products and their substitutes. Food Policy, 37, 760-770. doi: 10.1016/j.foodpol.2012.08.002 
Skunca, D., Tomasevic, I., Nastasijevic, I., Tomovic, V., \& Djekic, I. (2018). Life cycle assessment of the chicken meat chain. Journal of Cleaner Production, 184, 440-450. doi: 10.1016/j.jclepro.2018.02.274

Smetana, S., Palanisamy, M., Mathys, A., \& Heinz, V. (2016). Sustainability of insect use for feed and food: life cycle assessment perspective. Journal of Cleaner Production, 137, 741-751. doi: 10.1016/j.jclepro.2016.07.148

Smetana, S., Sandmann, M., Rohn, S., Pleissner, D., \& Heinz, V. (2017). Autotrophic and heterotrophic microalgae and cyanobacteria cultivation for food and feed: life cycle assessment. Bioresource Technology, 245, 162-170. doi: 10.1016/j.biortech.2017.08.113

Thrane, M., Paulsen, P.V., Orcutt, M.W., \& Krieger, T.M. (2016). Soy Protein: Impacts, Production, and Applications. Sustainable Protein Sources. Netherlands: Elsevier.

Wiedemann, S.G., McGahan, E.J., \& Murphy, C.M. (2017). Resource use and environmental impacts from Australian chicken meat production. Journal of Cleaner Production, 140, 675-684. doi: 10.1016/j.jclepro.2016.06.086

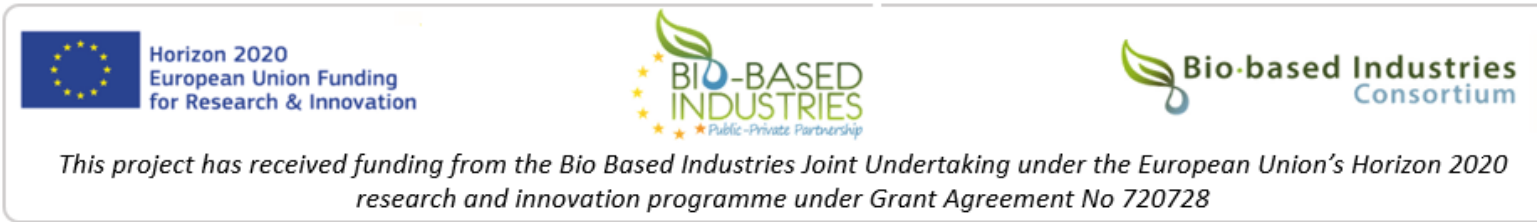

Received for publication: $\quad 01.12 .2020$

Revision received: $\quad 22.12 .2020$

Accepted for publication: $\quad 30.12 .2020$

\section{How to cite this article?}

Style - APA Sixth Edition:

Skunca, D., Romdhana, H., \& Brouwers, R. (2021, January 15). Rubisco protein production - LCA approach. (Z. Cekerevac, Ed.) MEST Journal, 9(1), 175-183. doi:10.12709/mest.09.09.01.20

Style - Chicago Sixteenth Edition:

Skunca, Dubravka, Hedi Romdhana, and Rob Brouwers. 2021. "Rubisco protein production - LCA approach." Edited by Zoran Cekerevac. MEST Journal (MESTE) 9 (1): 175-183. doi:10.12709/mest.09.09.01.20.

Style - GOST Name Sort:

Skunca Dubravka, Romdhana Hedi and Brouwers Rob Rubisco protein production - LCA approach [Journal] // MEST Journal / ed. Cekerevac Zoran. - Belgrade - Toronto : MESTE, January 15, 2021. 1 : Vol. 9. - pp. 175-183.

Style - Harvard Anglia:

Skunca, D., Romdhana, H. \& Brouwers, R., 2021. Rubisco protein production - LCA approach. MEST Journal, 15 January, 9(1), pp. 175-183.

Style - ISO 690 Numerical Reference:

Rubisco protein production - LCA approach. Skunca, Dubravka, Romdhana, Hedi and Brouwers, Rob. [ed.] Zoran Cekerevac. 1, Belgrade - Toronto : MESTE, January 15, 2021, MEST Journal, Vol. 9, pp. $175-183$ 